\title{
Research on Ideological Education of College Students of Finance and Economics under the Perspective of Integrity and Love Culture
}

\author{
Liguang Zhao \\ School of Taxation \\ Jilin University of Finance and Economics \\ Changchun, Jilin, China 130117
}

\begin{abstract}
Economic universities are the base to cultivate economic talents for the society. The morality and quality of these talents will directly influence the general mood of economic field of the society. It is important to let students accept the substantial spirit of integrity and love culture and shape personal morality with the help of environmental influence of economic universities and cultural carrier transmission. Economic universities can use activities of integrity and love culture to carry out ideological education for students in "the first period of time", "the second period of time", "fragmented time", "practice time" and "admission and graduation time" to cultivate excellent talents of high quality and morality in the economic field.
\end{abstract}

Keywords - integrity and love culture; finance and economics; university students; ideological education

\section{INTRODUCTION}

Our country is in the period of development and reform and has set up the object to build a moderately prosperous society in 2020. In the process of new reform, development and opening, various values and social trend of thought appear one after another. Economic universities that cultivate social economic talents should train comprehensive quality of university students and correctly guide three contemplations of them to carry out ideological education. The general secretary $\mathrm{Xi}$ Jinping once emphasized on the national propaganda and ideological work conference, "Spelling out Chinese excellent traditional culture is the prominent advantage of Chinese nation as well as the most profound culture soft power". The sixth Plenum of the 17th Central Committee of the Communist Party of China once proposed "carry forward Chinese culture and make efforts to build the power of socialist culture". "Integrity and love" in Chinese traditional culture are more important in today's social development. The learning environment of higher education is an important carrier to inherit excellent culture. It will play an important role in the growth of talents in economic universities to actively use culture and ideology to educate people, carry out the construction of integrity and love culture in economic universities, and strengthen cultivation and practice of socialist core values.

Fund project: Jilin Province Education Department "the 12th Five-Year Plan" Social Science Research Project (2015 No. 351); Jilin Province Scientific and Technologic Development Plan Funding Project (20150204040NY).

\section{REQUIREMENTS OF SOCIAL DEVELOPMENT OF INTEGRITY AND LOVE CULTURE}

\section{A. Inheritance of Chinese Traditional Culture}

Chinese traditional culture has accumulated for more than five thousand years. The integration of multiple nationalities and cultures finally form the unique centripetal force of Chinese nation as well as the same faith and belief. Integrity and love culture plays an important role in excellent traditional culture. The "kindheartedness" in Confucianism is the internal kindness and love advocated by Confucius, such as "the benevolent loves others" and "love others generally", and "love all the people and animals" of Menci as well as "universal love is called kindness" of Han Yu. Five virtues accumulated in the culture and history includes benevolence, righteousness, manners, wisdom and credit. Benevolence is the most important and other four virtues centers on it; the "integrity" is the combination of "integrity" and "credit", namely integrity and trustworthiness. "Integrity" means one should be real instead of acting recklessly, do not deceive himself and others. In the Doctrine of the Mean, "integrity" is the highest category. It is the "natural law", also called "the most sincere doctrine". It is human nature and doctrine endowed by the god. [1]

Integrity and love are moralities popular in Chinese excellent traditional culture. We still need to inherit and develop it today with rapid development of social economy. At the meantime, they are also value ideas with vitality. It is the responsibility and obligation of all the people in modern society to carry forward the representative moral value.

\section{B. Influence of Environmental Change in the New Era}

In face of the new situation and tasks, the Third Plenary Session of the 18th Central Committee of the Communist Party of China thinks in order to comprehensively build a moderately prosperous society and then build powerful, democratic, civilized and harmonious modern socialist country, realize the Chinese dream of the great rejuvenation of Chinese nation, we must comprehensively deepen reform on the new historical starting point. [2] With the deepening of reform and acceleration of social transformation, social risks faced by 
China are increasing. The crisis of social trust, love test and corruption of morality appear frequently. It makes people realize the importance of integrity and love.

Our country implements the strategy of strengthening the country through talents, who should have solid professional knowledge and good moral quality. In ideological education, universities should research how to improve comprehensive quality of college students and ensure they will become backbone after they get employed. Talents of economy cultivated by economic universities should have better moral quality. In this way, they can consciously resist dishonest behavior and put the thought of caring for others into the practice of work, establish overall consciousness and the thought of serving the collectivity, country and people, so as to ensure pure environment of social and economic field.

\section{Requirements and Practice of Socialist Core Values}

Our country is in the period of big development, big reform and big adjustment. In order to deal with complicated values and social ideological trend, on the Eighteenth National Congress of the CPC held in 2013, the Party Central Committee proposed the socialist core values with contents of prosperity, democracy, civility, harmony, freedom, equality, justice, the rule of law, patriotism, dedication, integrity and friendship. Patriotism, dedication, integrity and friendship are the moral rules of individual level of citizens.

To become a useful person and establish correct outlook on life, world outlook and values, college students must know honor and disgrace, have a kind heart and be honest. Especially those in social economic field, they must be more competent to identify the good and the bad, the true and the false as well as the good and the evil.

\section{IMPORTANCE FOR ECONOMIC UNIVERSITIES TO CARRY OUT INTEGRITY AND LOVE CULTURE CONSTRUCTION}

General Secretary Xi Jinping points out in the Thirteenth Collective Learning of the Political Bureau to "Deeply excavate and explicate the value of Chinese excellent traditional cultures to talk about kindness, pay attention to the sovereignty of the people, keep good faith, advocate justice, uphold harmony and seek things in common and let Chinese excellent traditional culture become important source that contain socialist core values." [3] After the Fifth Plenary Session of the Eighteenth Central Committee of the Communist Party of China, the environment, condition, task and requirement of development in our country show new changes. Understand new normal, adjust new normal, lead new normal, keep continuous and healthy development of economic society, put forward the key points to serve the people, promote the economy, transfer function, realize the rule of law, deepen the opening up and strengthen Party selfdiscipline. In the development period of economic society, people pay attention to how to promote the development of economy and create harmonious society. Under this environment, integrity and love culture as ethical basis is more important. Actively carry out integrity and love culture education among college students, cultivate them into economic backbones and elites with knowledge capability and moral character, consciously resist the temptation of corruption and immorality under the numerous and complicated social environment and "strictly cultivate their moral character, exercise authority and discipline themselves". Therefore, it seems more important to explore the method of ideological education in combination of integrity and love culture in students of finance and economics.

\section{A. Cultivate Moral Quality of Students through Integrity and Love Culture}

Students of finance and economics will work in social economic field after graduation. Nowadays, in social economic field and other fields, our country develops the work of combating corruption and upholding integrity, which have reached the deterrent effect of "hunting tigers and flies". If we guide from the source of public feeling, establish the moral character of integrity and incorrupt consciousness, these situations will be no longer in existence. Therefore, "the basis of university is to define and cultivate moral character". Excellent morality is the bright lamp to guide people. Students of finance and economics pay more attention to building excellent morality in learning and life. Schools should carry out integrity and love culture construction to carry out ideological education on students. In social development, all walks of life have realized these qualities of team members will decide the success of industries. Therefore, in talent recruitment, employers attach importance to rewards and punishment of students in school and personal moral quality. It has become important standard of employers to select talents.

\section{B. Cultivate Comprehensive Finance and Economics Talents through Integrity and Love Culture}

If the young is strong, the country will be strong. General Secretary Xi Jinping has great expectations on young people to "realize the Chinese Dream and be responsible", educate young people to firmly believe ideal and faith, temper noble character and swear they will never change to conduct hard work and plain living. These expectations should be the purpose for young people including young students to fight for. As reserve force of the finance and economics field, students of finance and economics should establish solid knowledge of finance and economics, exercise outstanding ability and integrate theoretical knowledge and social practice, establish correct view of life, world outlook and values in school, use the strength of integrity and love culture to set up personal noble character and apply these characters and abilities to socialist economic constructions and have sense of responsibility and gain something in the industry sector. The ideological education of economic universities should also center on this dream and steadily explore and cultivate compound talents of finance and economics with high quality, high ability and high intelligence quotient.

\section{Cultivate Spreader of Excellent Culture through Integrity and Love Culture}

Although college students will work in different fields of the society and becoming spreaders of excellent culture is not only the obligation of students of finance and economics, after graduation, some of them may become leading figures of the 
industry. Their words and deeds and morality will become bright flag of the industry. Good examples will endow the industry with positive energy, lead the development of people. Their new thoughts and new attitudes will drive and gradually influence the environment around them. Under the environment of building new economic society, it is necessary to adapt to the new normal and insist on, absorb and refer to good tradition, take the essence and discard the dross. Therefore, if students of finance and economics receive the edification of integrity and love culture at school, set strict demands on themselves and establish correct thoughts and "three reflections", after getting married and starting career, they will become spreaders of excellent culture in social and family environment and finally achieve the goal of harmonious society and happy family.

\section{Explore Ideological Education Method through the Construction of Integrity and Love Culture}

Each institution of higher learning has cultural deposits of its own. So in ideological education, economic universities require ideological educators have knowledge of economics and the thought to keep pace with social and economic development. In this way, they can keep pace with the knowledge and thinking of students in education and have common language. However, social development not only needs knowledgeable talents. There are also many people with "high intelligent quotient and low emotional quotient". In order to better cultivate compound talents of finance and economics, it is the common wish of ideological educators to explore proper methods to educate students of finance and economics. Under the influence of excellent traditional culture, carry out activities of integrity and love culture to let students build integrity awareness, resist corruption and learn to devote love and be grateful. Schools can implement measures to edify students from the source of thought, exert a subtle influence on students to establish integrity and love consciousness. It can spread Chinese excellent traditional culture and exploit new thought and method for universities of finance and economics as well as indicate direction to cultivate and educate students from the perspective of moral education.

\section{IMPLEMENTATION SITUATION OF INTEGRITY AND LOVE CULTURE IN ECONOMIC UNIVERSITIES}

Economic universities are to cultivate professional talents for national economic field with the reform and opening up and market economy in the education system of our country. Their purpose is to cultivate compound talents with noble moral consciousness and high quality and ability that can adapt to market economy development with socialist characteristics and comply with the time development. Therefore, universities not only pay attention to the learning of professional knowledge but also attach importance to "all around development of moral, intellectual, physical, aesthetics and labor education" on students. Each school are exploring and implementing the educational way proper for the development of students on the basis of cultural spirit of its own.

As an economic university, since the establishment, JC University has cultivated batches of talents of economics. Now many schoolfellows have become leading figures in the industry field. Although they have high social status, they stay true to the mission. Many schoolfellows still pay attention to the development of school and the growth of students. Their gratitude for alma mater becomes the love for their school. They have set good examples for students at school via dedication to work and integrity spirit.

The spirit of school motto of JC University of "clarifying morality and upholding integrity" has been inheriting by students and teachers. As high level base to cultivate talents for the society and the country, the school insists on cultivating students into honest talents with simple style and solid foundation that have rich thoughts, handle affairs steadfastly. At the meanwhile, it closely combines humanistic spirit, conducts love education and carries forward love culture, promotes love inheritance and cultivates students with kindness, closely integrates socialist core values with the inheritance of integrity and love culture. Therefore, under edification of such cultural deposits, students will benefit a lot.

JC University actively carries out integrity education in the construction of integrity culture and publicizes integrity culture through various forms and campus activities, such as carry out the essay competition of integrity, integrity test without people to invigilate, integrity declaration in deciding on awards through discussion, integrity demarcation of students with family economic difficulties, integrity credit repayment of student loan and integrity employment of graduates. These methods let college students who are going to become talents in economic field implement the integrity consciousness in thoughts and actions and establish credibility culture of the school.

When building integrity culture, JC University also bases on characteristics of young people and building love culture, which has achieved good effects. For example, more than four hundred students of $\mathrm{F}$ college of the school in 10 sessions of 24 years participate in the "relay baton of love" to take care of ant Zhang Jiuzhen; SW college has insisted on carrying out the volunteer service activities of "surrogate mother" with Youth League branch as the unit for 17 years. The love outreach carried out by college students in the 20th anniversary of municipal surrogate mother is praised as "mother with big wisdom" and "the most beautiful surrogate mother". Moreover, the deeds of Zhang Shangyun, "Dutiful Son of the Times" and Zhang Shuang, one of the ten figures that "Touch Jilin" not only touch Jilin but also cause wide repercussions in the whole country. There are many activities of working as volunteer teacher and volunteer service. The school also depends on the selection of figures that "Touch the School of Taxation", deeply excavates advanced figures and collectivities and integrates love education in ideological education to guide students to develop good morality and sentiment.

\section{WAYS FOR ECONOMIC UNIVERSITIES TO CONDUCT CONSTRUCTION OF INTEGRITY AND LOVE CULTURE}

Sukhomlinskii once said without emotions, morality will become uninteresting hollow words and can only cultivate hypocrite. Economic universities in different areas have different school-running characteristics. Meanwhile, because of the difference of regional culture, the cultural deposits of 
schools are also different. Therefore, exploring ways and methods appropriate for the construction of integrity and love culture in school will be targeted. However, no matter how to carry out the construction of integrity and love culture, the ultimate goal of school is to cultivate qualified talents with high quality and character in economic field. Exerting characteristics of the school and summarizing advantages of its own can reach the purpose of shooting the arrow at the target. Ways of ideological education on students to use the construction of integrity and love culture in economic universities include:

\section{A. Carry out Education of Integrity and Love Culture in "the First Period of Time"}

College students learn most theoretical knowledge in the classroom with professional teachers. We should size "the first period of time" of education on students at school in "the first class" of learning. Because exam-oriented education still exists in our country, most students learn with the purpose of passing the examination before admission. It fundamentally separates "teaching" and "cultivation". "Give a man a fish and you feed him for a day. Teach him how to fish and you feed him for a lifetime". "Teaching" means imparting existing cultural knowledge to learners, while "cultivation" means cultivating the character of learners. Pay attention to imparting knowledge and neglecting moral education will inevitably influence comprehensive quality of learners. Carrying out the education of integrity and love culture in universities will have good ideological guidance on learners. Some scholars think the main reason of lacking integrity education is the separation of moral knowledge and value, moral understanding and faith, moral knowledge and action. [4] It just embodies the one-sidedness of the present moral education, which only teaches theoretical knowledge and neglects education of moral quality, only publicizes patriotism, integrity and obedience of law and neglects the development of good habits.[5] Therefore, professional teachers in school should give guidance on learning as well as combine with the practice, set a good example of integrity and love and let students receive dual guidance of thought and reality in "the first period of time" in class.

\section{B. Excavate Examples and Everyone Strives to Be A Model in "the Second Period of Time"}

Mao Zedong once said, "the power of example is endless". There are teachers, students, administrative staff and logistics service personnel in school. Except for the time in class, students still have a lot of extracurricular time, which belongs to "the second period of time". It can be used to carry out the publicity and education of integrity and love among students. In this environment, there must be people or teams that have made outstanding contributions to integrity and love culture. Therefore, it will play a role of getting twofold results with half the effort by excavating typical examples and reasonably publicizing and guiding. "Profound knowledge makes a teacher; moral integrity makes a model." Teachers exert the role of model and personality charm in class. Meanwhile, excavate deeds of kind help and selfless contribution of teachers, model deeds of excellent teachers; take advantage of the economic universities, guide talents to form correct attitude towards economics and finance through the example set by important departments in the system; let teaching units play the role of integrity in invigilation and marking; let power sectors play fair and discharge duties with self-discipline; graduates set an example of being gratitude to the Alma Mater. All people educate and set example, and let students in school feel the emotional conveyance of integrity and love.

\section{Use "Fragmented Time" to Let Students Be Influenced by What They Constantly See and Hear and Educate Them Everywhere}

In the information era with rapid development of network, people seize every minute to enrich themselves. Mobile devices have become necessities of students. They use it to get information and learn. So the "fragmented time" neglected by people once also has been fully used. Actively use existing ways of publicity in school. The blackboard newspaper, poster, publicity column, newspaper column and broadcast are important bases to carry out ideological education and guidance on students. Nowadays, network and new media develop rapidly. These media also attract the attention of students in the new era. The traditional ways of publicity increase the degree of attraction and absorb new thought. If we use microblog, WeChat, Renren to conduct novel publicity and education easy for students to accept, it will greatly help the education of integrity and love culture on students at school. Therefore, if the "fragmented time" can be used for integrity education and love culture, it will educate students to be influenced by what they constantly see and hear and then establish correct ideas.

\section{Carry out Construction of High Quality Culture in School and Integrate Ideological Education in "Practice Time"}

The cultural atmosphere at campus can embody the efforts made by school to train the ability and quality of students as well as let students gain achievements in practice. High quality activities carried out by students in economic universities center on academic activities with specialized knowledge. There are also club activities on the basis of cultural deposits of the school. In "practice time", students gain theoretical knowledge as well as personal experience. In the construction of integrity and love culture, we cannot educate students only by relying on theoretical knowledge. Experience is the best teacher. Therefore, the construction of integrity and love culture must be applied to actual activities instead of only depending on publicity. It will promote the construction of high quality cultural activities in school by carrying out similar high quality activities such as national "Youth Entrepreneurship Competition". For example, conduct activities of finance and economics with the theme of "work and handle affairs with integrity" from professional perspective, advocate volunteer service with dedication of love, or hold seminar with the theme of examples of figures with integrity and love. All of these will help students to get personal feelings in "practice time" and then improve personal ideological awareness. 


\section{E. Reasonably Use "Admission and Graduation Time of Students" and Combine Education with Restriction}

"Nothing can be accomplished without norms." This proverb explains the importance of order very well. Students of economic universities will work in social economic field after graduation. Without good quality and morality, their development and atmosphere of the industry will be influenced. Therefore, he integrity and love culture education in universities can guide students to form integrity consciousness, shape the morality of kindheartedness. More important, it can help students to establish correct "three reflections" on ideology. In this way, they can set a good example in society and then promote the environment of integrity and love in society, shape harmonious society. Good ideological education is important. But if the ways and customs in society is unhealthy, and if things continue this way, it will corrode the thought. For example, the "moth", "abandonment" and "loan fraud" exist in society. So universities should seize the "admission and graduation time" of students. When entering universities, students have simple ideas just like a blank paper. It is of importance to lay a solid foundation. Good educational work should have "consciousness at earlier stage". When students graduate, universities should also pay attention to their ideological trend, combine publicity, individual discussion and warning and reflections and let students consolidate the achievements of ideological consciousness of the four years again. The proverb says, "Do not fail to do good even if it is small; do not engage in evil even it is small". Students should improve personal quality and then influence people around them as well as the ways and customs of the whole society. Universities should carry out ideological education and improve restriction mechanism of school and society, such as the credit archive construction of the school, improvement of related rules and regulations and reasonable system of rewards and penalties. It will not only reduce unhealthy phenomenon in society but also play the role of restriction and warning in reality. [6]

\section{CONCLUSION}

Reasonable guidance and education of the ideology of students in economic universities is a perspective that people pay attention to in the development of talents in social economic field. General Secretary Xi Jinping advocates college students to become talents with "ideal, pursuit, sense of responsibility, outstanding achievements, quality and accomplishment". The integrity and love in traditional culture are important contents spreading in students of economic universities and can be used for reference. Carrying out ideological guidance and education on learning, life and work of students at different stages will be bound to successfully cultivate college students with "Six Things" required by society and our country, and then cultivate excellent talents with high quality and character in economic field.

\section{REFERENCES}

[1] Guo Qiyong, Ye Hui. Core Values Should Have Chinese Elements and Reality--Discussion on the Necessity to Bring it in the Category of
"Kindness" and "Integrity" [EB/OL]. Guangming Daily, the 7th edition, Mar. 24, 2012

[2] Hong Yinxing. Deepen the Reform to Solve Three Problems Concerning Economic Development in the New Period [J], Theoretical Reference, Dec.1, 2013

[3] Xi Jinping. The Thirteenth Collective Learning of the Political Bureau of the CPC Central Committee [EB/OL], Xinhua Net, Feb. 25, 2014

[4] Guo Kai, Hou Qihai. Current Situation and Countermeasures of Integrity Education in Universities in the New Period [J], Journal of Shandong Youth University of Political Science, 2006(5): 76-78

[5] Song Jianxiao. Remolding of Integrity Culture Education in University [J], Journal of Jimei University, 2013(12):46-49

[6] Zhao Liguang, Liu Mingju. Analysis on the Influence of Integrity and Love Culture Education in Economic Universities on Talent Cultivation [J], Journal of Green Science and Technology, 2015(12). 